\title{
REPRODUCTION AND GROWTH OF XEROLENTA OBVIA (MENKE, 1828) (GASTROPODA: EUPULMONATA: GEOMITRIDAE) IN LABORATORY CONDITIONS
}

\author{
ElżBIETA KuŹNIK-KOWALSKA ${ }^{1 *}$, MAŁGORZATA BARAN ${ }^{1}$, MAŁGORZATA PROĆKÓW² $^{2}$ \\ ${ }^{1}$ Department of Invertebrate Systematics and Ecology, Institute of Biology, Wrocław University \\ of Environmental and Life Sciences, Kożuchowska 5b, 51-631 Wrocław, Poland \\ (e-mail: elzbieta.kowalska@upwr.edu.pl, malgorzata.b.baran@gmail.com); \\ EKK (i) https://orcid.org/0000-0002-5509-0336 \\ ${ }^{2}$ Museum of Natural History, University of Wrocław, Sienkiewicza 21, 50-335 Wrocław, Poland \\ (e-mail: malgorzata.prockow@uwr.edu.pl); (1) https://orcid.org/0000-0003-2240-7306 \\ *corresponding author
}

ABSTRACT: Laboratory observations made it possible to ascertain some life cycle parameters of Xerolenta obvia. The eggs are laid in clutches of 15-65 (mean 32) or rarely singly; they are partly calcified, milky white, oval or almost spherical, with a mean size of $1.37 \times 1.46 \mathrm{~mm}$; time to hatching is 11 to 28 days (mean 18); hatchlings have shells of 1.5-2.0 whorls (mean 1.7); hatching success is ca. $57 \%$. Sexual maturity (first egg) is reached by snails at 4.25-5.2 whorls (mean 4.85) within 290-660 days. The average life span is two years. Neither uniparental reproduction nor egg or sibling cannibalism was observed. The life-history traits of $X$. obvia are compared with some xerophilous species of similar size.

KEY WORDS: Geomitridae; land snails; life history; growth rate; xerophilous snails

\section{INTRODUCTION}

Xerolenta obvia (syn. Helicella obvia) originates from south-eastern Europe (WIKTOR 2004, WELTERSCHULTES 2012), from where it was introduced into Central and Western Europe. It has since extended its range further (URBAŃSKI 1957, WOJTAŚ \& WOJTAŚSTOKŁOSA 2001). The snail dispersed mainly along railway embankments and rivers (RIEDEL 1988). Now its distribution extends from Asia Minor to the eastern and central Balkans, N. Italy, Carpathian countries (in the east to Moldova and N. Ukraine) and to the Baltic Sea (Welter-Schultes 2012). In Central Europe it inhabits Poland, the Czech Republic, Slovakia, Hungary, Switzerland, Austria and Germany, reaching SE. France (KERNEY et al. 1983). In Poland $X$. obvia occurs in almost the whole country, occupying mainly lowlands (WIKTOR 2004), while in Bulgaria and the Alps it reaches altitudes up to 2,000 $\mathrm{m}$ a.s.1. (WelTER-SCHUlTES 2012). Outside Europe it was introduced to Canada (in 1969 and
1972 to Bethany, Ontario) and the United States (by 2002 to Wayne County, Michigan and by 2012 to Cascade County, Montana) (GRIMM \& WigGINS 1975, FORSYTH et al. 2015, BIRDSALL et al. 2019).

The systematic position of $X$. obvia has changed. It was included in the Helicidae Rafinesque, 1815 (KERNEY et al. 1983) or the Hygromiidae Tryon, 1866 (BOUCHET \& Rocroi 2005, SCHILEYKO 2006). Now it is classified in the Geomitridae C. Boettger, 1909 (RAZKIN et al. 2015), whose members mostly occur in xeric habitats. The information on geomitrid life cycles and/or seasonal dynamics has been reported in several studies (e.g. LAZARIDOU-DIMITRIADOU 1981, STAIKOU \& LAZARIDOU-DIMITRIADOU 1991, HÄNSEL et al. 1999, KISS et al. 2005, BAKER 2012). The information on the biology of $X$. obvia includes field observations on climate-dependent variations in life histories in the Mediterranean and Central Europe (LAZARIDOU-DIMITRIADOU 1995, 
LAZARIDOU \& CHATZIIOANNOU 2005, MARZEC et al 2020); there is also a study further east in Belarus (ZEMOGLYADCHUK 2019). Some fragmentary data are also provided by FRÖMMING (1954) and BIRDSALL et al. (2019).

\section{MATERIAL AND METHODS}

The source material for the laboratory culture of X. obvia (131 individuals of different ages, i.e. 1.5-3.5 whorls) was collected on two occasions: 55 snails kept in groups and 15 snails kept singly, collected as 128 eggs on the 17th of October 2015; and 50 snails kept in groups and 11 snails kept singly, collected as juveniles (mean number of whorls: 2.96; range $2.25-3.5 ; \mathrm{SD}=0.25 ; \mathrm{n}=61$ ) on the 18 th of June 2016. Additionally, a group of 50 snails (2.0-4.0 whorls) were kept in a glass vivarium since October 4th, 2017. All the snails and eggs originated from the village of Piotrkowiczki (SW. Poland, $51^{\circ} 16.12 ' \mathrm{~N}$, $17^{\circ} 02.12^{\prime} \mathrm{E} ; 190 \mathrm{~m}$ a.s.1.).

To check the possibility of uniparental reproduction, 26 individuals were kept singly from their earliest juvenile stages until death. The remaining 105 snails were kept in pairs (10 pairs) and groups: 2 groups of 3 individuals, 5 groups of 5 individuals, 3 groups of 8 individuals, 3 groups of 10 individuals.

The snails were kept in plastic containers of different sizes depending on the number of individuals $(6 \times 7.5 \times 5 \mathrm{~cm}$ for singly kept snails and pairs; $11.5 \times 7 \times 7 \mathrm{~cm}$ for groups of 3 individuals; $15.5 \times 12.5 \times 5 \mathrm{~cm}$ for groups of 5 individuals; $15.5 \times 12.5 \times 7 \mathrm{~cm}$ for groups of 8 and 10 individuals). Eggs and hatchlings were kept in separate Perti dishes (5-10 cm diameter) lined with damp tissue paper and moist soil. The substratum of the containers consisted of a layer of damp tissue paper with a thin layer of gardening soil (natural, with no supplements) on top, which was replaced with sandy gravel after October 4th, 2017. The gravel was brought from the natural habitat and sterilized at $70{ }^{\circ} \mathrm{C}$ for $72 \mathrm{~h}$. The containers were aired and the substratum was changed at least once a week. Water and food (iceberg lettuce) were supplied as needed. Dolomite tablets constituted the source of calcium. The dish-
This paper presents the results of laboratory observations on the life cycle of the species and compares the results with those obtained by other authors and/or from other regions for some European xerophilous species of similar size.

es and containers with snails were kept in a climate chamber in regular conditions of temperature (day $22^{\circ} \mathrm{C}$, night $18^{\circ} \mathrm{C}$ ) and humidity (80\%), with a $12: 12$ $\mathrm{h}$ lighting regime (fluorescent lighting). The glass vivarium $(30 \times 30 \times 45 \mathrm{~cm})$ was placed in the laboratory room, where the temperature ranged from $17^{\circ} \mathrm{C}$ in winter to $28^{\circ} \mathrm{C}$ in summer, and a humidity of ca. $80 \%$ was maintained by regularly wetting the tissue paper. In these conditions one fragmentary copulation and six egg clutches were recorded.

The observations in a climate chamber were to investigate the capability/incapability of uniparental reproduction $(n=26)$, egg laying, clutch size, time to hatching, hatching success, growth rate (105 snails kept in groups vs 26 snails kept singly), maturation (i.e. until the first egg laying was observed, $\mathrm{n}=5$ ), life span (period from hatching to death of snails with at least 4.8 whorls, 884 days, $\mathrm{n}=12$ ) and possible cannibalism $(n=45)$. Survivorship was calculated based on Kaplan-Meier estimate.

The growth rate of individuals was assessed through counting whorls at 30-day intervals using EHRMANN's method (1933). To ascertain the clutch size and hatching success, likely egg-laying places were searched at least once a week and during periods of intense observations (e.g. reproductive period) every day or two, the eggs and hatchlings were counted, and the time to hatching recorded. A sample of eggs $(n=100)$ were measured with a calibrated eyepiece to the nearest $0.025 \mathrm{~mm}$. The measurements included 60 eggs laid by snails during their collection in the field and transport to the laboratory as well as two clutches of 20 eggs each laid by snails in the laboratory on December 18th, 2017 and March 9th, 2018. To test cannibalism, hatchlings (test 1) and adults (test 2) were offered conspecific eggs at different stages of development.

\section{RESULTS}

\section{COPULATION, EGG LAYING, TIME TO HATCHING AND HATCHLINGS}

The fragmentary copulation (its last stage: retracting the copulatory organs) was observed in the laboratory on September 16th, 2017 and February 23rd, 2018, and in the field on October 4th, 2017
(Fig. 1). During copulation the snails were in a horizontal position, attached to each other side-to-side. Copulations and sperm transfer were reciprocal. After the copulations, each partner was placed in a separate container in the climatic chamber. Only after the mating in September, one of the snails laid 30 eggs in a single clutch 16 days later. Of these, seven 


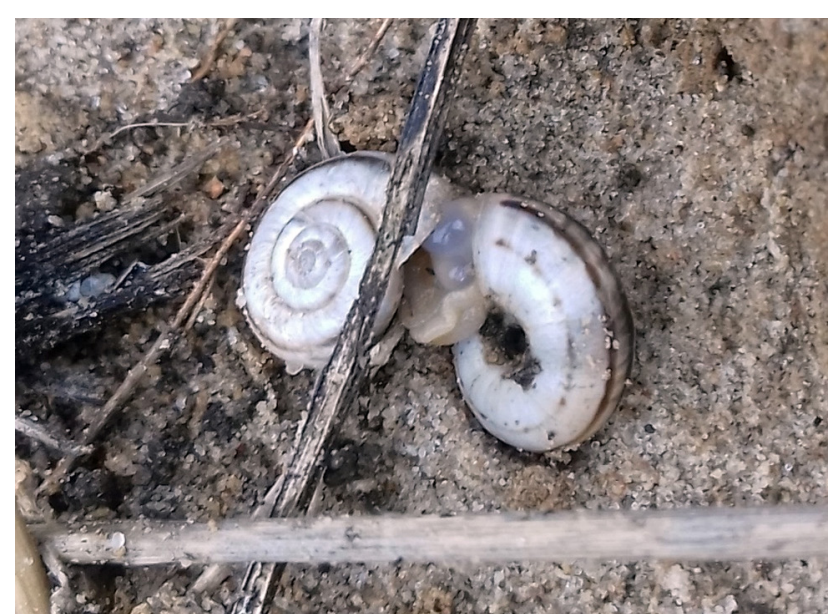

Fig. 1. Mating of X. obvia in the field (4 Oct 2017, photo E. KUŹNIK-KOWALSKA)
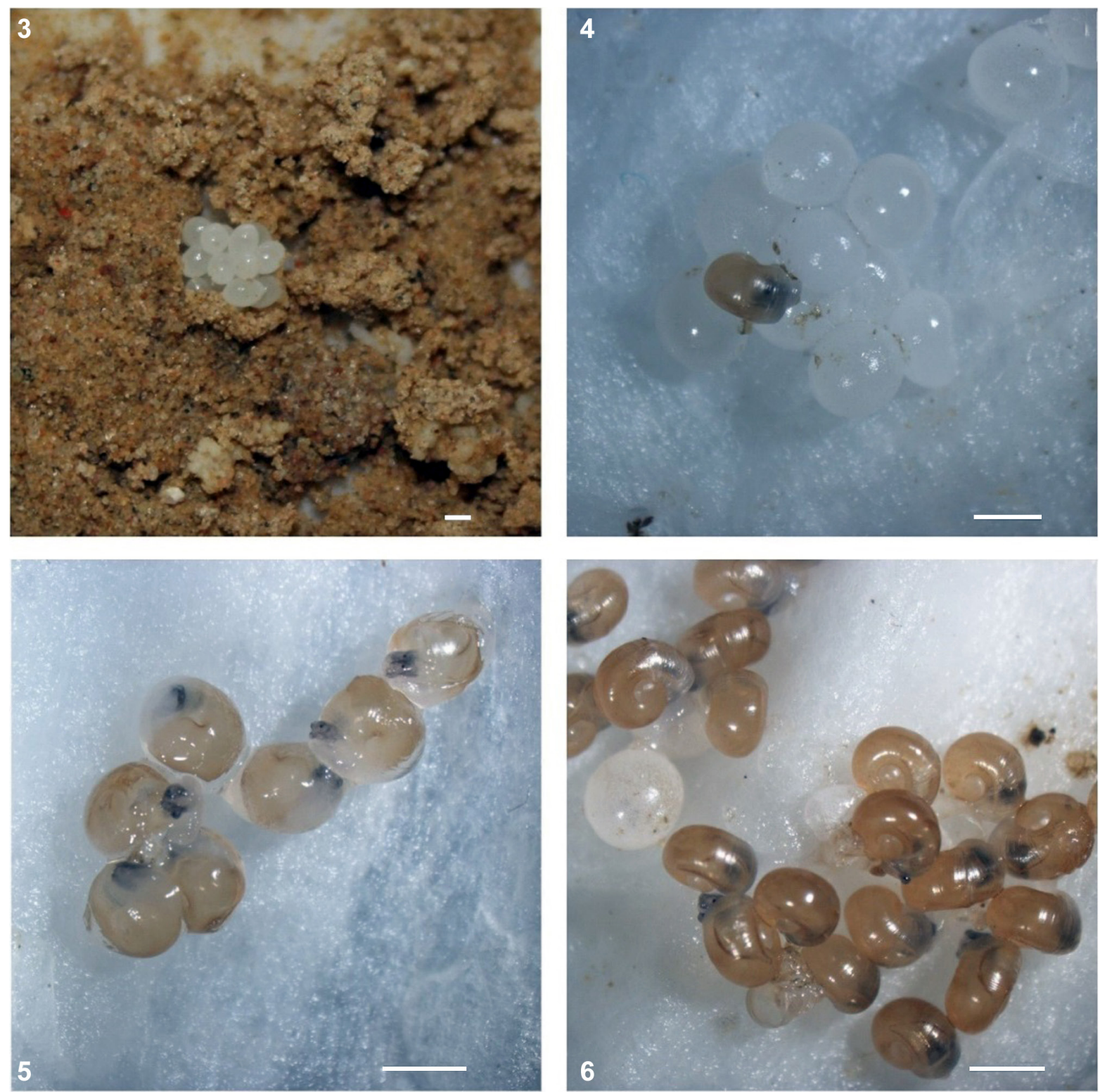

Figs 3-6. X. obvia: freshly laid eggs (3), juvenile during asynchronous hatching (4), nearly hatched juveniles in semi-translucent envelope (5), and five-day hatchlings (6) (photos E. KuŹNIK-KOWALSKA). Scale bars 1 mm 
eggs hatched and five hatchlings survived until the end of the study. The other snails observed copulating did not lay eggs.

None of the 26 snails kept singly laid eggs whereas 13 out of the 155 snails kept in groups did lay eggs. The difference in proportion was not statistically significant (Fisher's exact test $\mathrm{p}=0.2$ ). Eggs were laid mainly in autumn (October 2016, $\mathrm{n}=28$; October 2017, $\mathrm{n}=290$ ), then in winter (DecemberJanuary 2017, $\mathrm{n}=60$ ) and spring (March-April 2017, $\mathrm{n}=45$ ). Of the total of 423 eggs, 6 were laid singly and the rest in 13 clutches. The mean clutch size was 32 eggs (range 15-65; SD = 14.8; $n=13$ ) (Fig. 2). The eggs were laid mainly in holes dug in the sandy gravel, but also directly on the tissue paper. Newly laid eggs were partly calcified, milky white, and oval or almost spherical. Initially they were shiny as a result of the covering mucus layer; then they became cream-coloured and matt, and finally light brown, semi-translucent, so that the young snail could be seen (Figs 3-6). The mean egg width was $1.37 \mathrm{~mm}$ (range 1.2-1.6 mm; SD $=0.11 \mathrm{~mm} ; \mathrm{n}=100$ ), while the mean egg length was 1.46 (range $1.2-1.8 \mathrm{~mm}$; $\mathrm{SD}=0.12 ; \mathrm{n}=100)$.

The first egg-laying (sexual maturity) was directly observed in snails with 4.25-5.2 whorls (mean 4.91; $\mathrm{SD}=0.38 ; \mathrm{n}=5$ ). These sizes were reached 290 660 days after hatching (mean 448.6; $\mathrm{SD}=158.35 ; \mathrm{n}$ $=5$ ). The smallest egg-laying snail ( 4.25 whorls) laid 28 eggs, which did not hatch. This snail kept growing for the next five months to reach 4.5 whorls. The juveniles hatched from eggs laid by one snail with 5.0 whorls, which grew to 5.1 whorls within five months, and by three other snails (with 5.0, 5.1 and 5.2 whorls), which did not grow further.

The time to hatching ranged from 11 to 28 days (mean 18; $\mathrm{SD}=8.04 ; \mathrm{n}=100$ ). The hatching was asynchronous; juveniles of the same clutch hatched over 1-3 days. The newly hatched juveniles had translucent shells and bodies; their shells had 1.5-2.0 whorls (mean 1.7; $\mathrm{SD}=0.11 ; \mathrm{n}=100$ ) The hatching success was $57 \%$ (variation between clutches 24-100\%; SD $=22.6 \% ; n=423$ eggs; $n$ $=13$ clutches). Out of six single eggs, five (83\%) hatched.

No egg cannibalism was observed among juveniles or adults, even in the absence of other food; likewise, no juvenile-juvenile and adult-juvenile cannibalism occurred.

\section{GROWTH, SURVIVORSHIP AND LIFE SPAN}

The growth rate of individuals of $X$. obvia kept in isolation and in groups was similar (Fig. 7), suggesting that it did not depend on the density. The proportional growth rate was more or less consistent throughout whole growth unless there occurred an unexpected acceleration in snails between ca. 3.5 and 4.5 whorls. The juvenile snails suffered very high mortality in the laboratory culture. Among 131 young snails observed, 13 survived 884 days, i.e. to the end of the laboratory culture (10\%). $25 \%$ of all juveniles died during 130.5 days, $50 \%$ snails survived 300 days and $25 \%$ survived longer than 582 days (Fig. 8). The life span of $X$. obvia ranged from 655 days (ca. 22 months) to 884 days (ca. 30 months) (mean $=772$; $\mathrm{SD}=69 ; \mathrm{n}=12$ ).

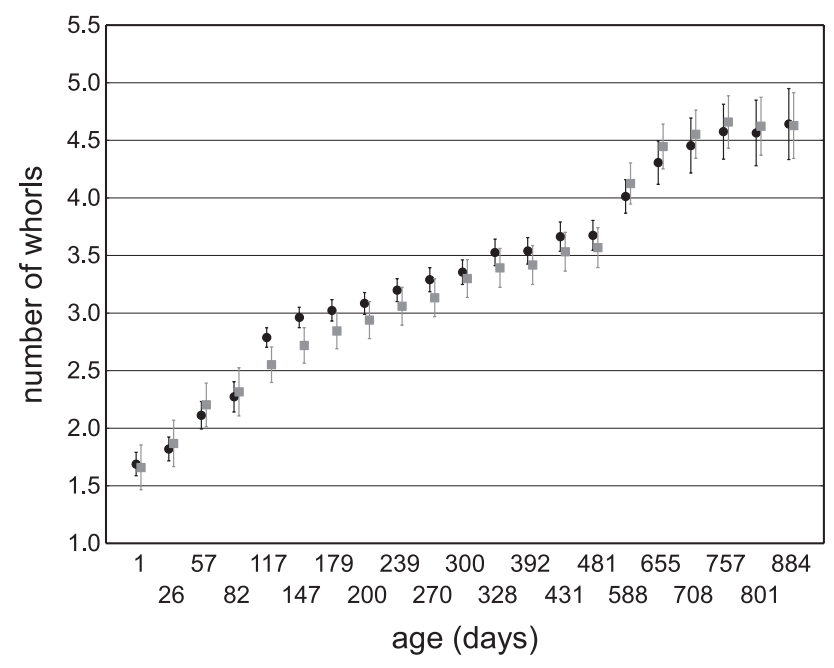

Fig. 7. Mean growth of $X$. obvia individuals kept in groups (circle, $n=105$ ) and singly (square, $n=26$ ). The error bars represent $95 \%$ confidence intervals

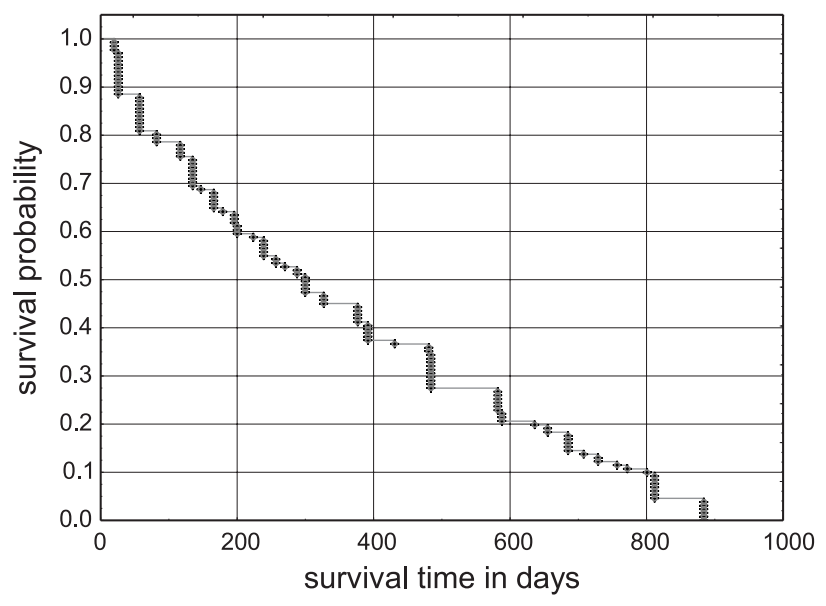

Fig. 8. Survivorship function of 131 X. obvia individuals 


\section{DISCUSSION}

The knowledge of pulmonate life cycles is still very scanty, and varies much among the various families (HELLER 2001). Members of the Geomitridae sensu RAZKIN et al. (2015), which thrive in predominantly xeric habitats, are no exceptions. We managed to observe egg and clutch size, time to hatching, the appearance of hatchlings and the growth of X. obvia in the laboratory, and - in an earlier study - the differences in growth pattern, population dynamics and shell morphology between two natural populations (MARZEC et al. 2020). These field observations pertained to two distant populations from areas which varied in terms of climatic regime. Here we attempt to place the information in the context of a few arbitrarily chosen European xerophilous species of similar size.

In many xerophilous gastropods from the Mediterranean region reproductive and egg-laying periods are similar regardless of the location. In this area the reproduction takes place in autumn (MOQUIN-TANDON 1855, BERNER 1941, STAIKOU \& LAZARIDOU-DIMITRIADOU 1991, LAZARIDOU \& CHATZIIOANNOU 2005). In Central and Eastern Europe $X$. obvia also reproduces in autumn (ZEMOGLYADCHUK 2019, MARZEC et al. 2020), but snails introduced to Montana in the USA can lay eggs both in autumn and spring (BIRDSALL et al. 2019). In French populations of Xeropicta derbentina (Krynicki, 1836) (syn. X. arenosa) prolonged egg-laying was observed from September to January, with some eggs also recorded in March (KIsS et al. 2005). In a xerophilous helicid Theba pisana (Müller, 1774) the breeding period included summer and autumn in Britain and northern France, but the reproduction occurred in autumn and winter in the Mediterranean (COWIE 1984).

In SW. England a smaller snail Candidula intersecta (Poiret, 1801) laid eggs in November-December and early summer, the timing apparently varying according to rainfall and moisture balance (BAKER 1968). We observed egg-laying by the snails collected in October. Field studies revealed that the snails from this population in SW. Poland were more plastic compared to the population from the distant geographic region in NE. Poland. The SW. population reproduced mainly in autumn, but juveniles of the smallest recorded age class were present from April to August. Few adults could survive for more than one season (MARZEC et al. 2020).

The field studies indicate a predominantly annual life cycle of $X$. obvia and show that its growth rate depends on climatic conditions and is negatively correlated with the age of snails (MARZEC et al. 2020). Since the juveniles of $X$. obvia survived in the labora- tory very poorly, doubts may arise whether the mean life span, estimated for two years, was real. However, our data did not differ from those published by other authors, who reported longevity of X. obvia for 1-3 years (LAZARIDOU \& CHATZIIOANNOU 2005, WELTER-SCHULTES 2012). As determined by width, weight and number of whorls, $X$. obvia exhibits high variation in growth rate but develops fastest at $20^{\circ} \mathrm{C}$. Individuals at both $12{ }^{\circ} \mathrm{C}$ and $28^{\circ} \mathrm{C}$ were noticeably smaller than snails reared at $20^{\circ} \mathrm{C}$. Moreover, snails reared at $28^{\circ} \mathrm{C}$ experienced high mortality (BIRDSALL et al. 2019). Variations in growth rate and life span are suspected to be a response of $X$. derbentina to an attenuation of summer drought due to occasional rain (KISS et al. 2005).

Xerolenta obvia reached maturity in the year following hatching, similarly to that observed in the French populations of Cernuella virgata (Da Costa, 1778) and Helicella itala (Linnaeus, 1758) - two species of size, shell structure and habitat requirements similar to those of $X$. obvia (MOQUIN-TANDON 1855). There is, however, substantial variation in the life cycles, depending on the habitat type or climate (KISS et al. 2005, LAZARIDOU \& CHATZIIOANNOU 2005, BAKER 2012, MARZEC et al. 2020). C. virgata normally had a single generation annually with massive egg hatching in autumn and fast juvenile growth until the next spring in Australia (POMEROY 1969). Its life cycle may also vary between habitats: annual in pasture-cereal rotations or biennial in permanent pastures (BAKER 1996, 2008). T. pisana, X. derbentina and $X$. obvia are able to switch from an annual to a biennial cycle in response to climatic conditions or population density (CowIE 1984, KIsS et al. 2005, LAZARIDOU \& CHATZIIOANNOU 2005). Given such plasticity as well as fast growth and reproduction of these snails, and the fact that they form very abundant populations, it is likely that, with a climate change, the species will be able to invade new regions of the world. T. pisana and C. virgata invaded North America and southern Australia, becoming serious pests of crops and pastures and difficult to control (COWIE et al. 2009, BAKER 2012). There are no published observations in Europe of X. obvia being an agricultural pest. Nevertheless, its recent introduction in Montana, USA, is seen as a potential risk for grain and hay production and for export markets. This snail is of particular concern since it is known to feed on fodder crops (BIRDSALL et al. 2019). X. derbentina was successfully introduced to south-eastern France from Eastern Mediterranean Europe (KISS et al. 2005). In the near future, we may expect a further increase in the number of alien gastropods to expand across Europe and other continents (HATTELAND et 


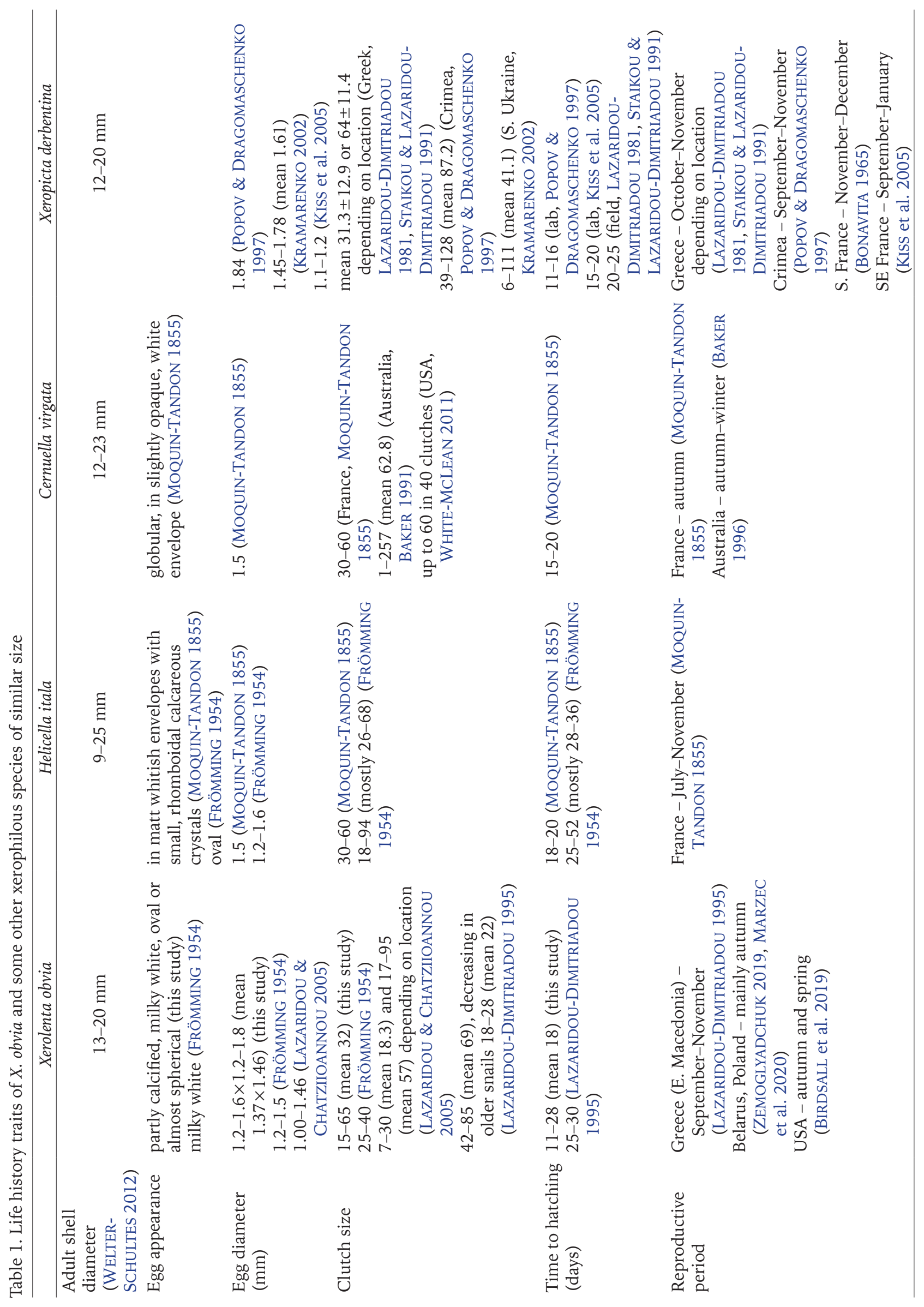


al. 2013, SARMA et al. 2015, ProćKów et al. 2019). Several species, e.g. C. virgata, Arion vulgaris, Monacha cartusiana, Helix lucorum, Hygromia cinctella, Cornu aspersum are well adapted to human-impacted environments (PELTANOVÁ et al. 2012, DedOV et al. 2015, WALTON 2017, PÁlL-GERGELY et al. 2019).

The differences in life history of $X$. obvia reported by various authors indicate inter-population differences in life cycle traits. They are summarised in Table 1 and compared with some xerophilous species of similar size. The intraspecific differences in the egg size and the number of eggs could be due to population densities or to climatic differences among the sites studied. An adaptive evolutionary response to the climate may be manifested among others by the small number of eggs in more arid areas (LAZARIDOU-DIMITRIADOU 1981, STAIKOU \& LAZARIDOU-DIMITRIADOU 1991, LAZARIDOU \& CHATZIIOANNOU 2005). The fecundity (i.e. total number of eggs produced, numbers of clutches and

\section{REFERENCES}

BAKER G. H. 1991. Production of eggs and young snails by adult Theba pisana (Müller) and Cernuella virgata (Da Costa) (Mollusca, Helicidae) in laboratory cultures and field populations. Australian Journal of Zoology 39: 673-679. https://doi.org/10.1071/ZO9910673

BAKER G. H. 1996. Population dynamics of the Mediterranean snail, Cernuella virgata, in a pasture-cereal rotation in South Australia. In: HENDERSON I. F. (ed.). Slug and snail pests in agriculture. BCPC Farnham, British Crop Protection Council (BCPC) Symposium Proceedings 66: 117-124.

BAKER G. H. 2008. The population dynamics of the Mediterranean snails, Cernuella virgata, Cochlicella acuta (Hygromiidae) and Theba pisana (Helicidae) in pasture-cereal rotations in South Australia: a 20-year study. Australian Journal of Experimental Agriculture 48: 1514-1522. https://doi.org/10.1071/EA08031

BAKER G. H. 2012. The population dynamics of the Mediterranean snail, Cernuella virgata (Da Costa, 1778) (Hygromiidae), in continuous cropping rotations in South Australia. Journal of Molluscan Studies 78: 290296. https://doi.org/10.1093/mollus/eys015

BAKER R. E. 1968. The ecology of the wrinkled snail Helicella caperata Mont. on the Braunton Burrows sand dune system. Proceedings of the Malacological Society of London 38: 41-54.

BERNER L. 1941. Guide malacologique des environs de Marseille, Mollusques terrestres et dulcicoles. Bulletin du Museum d'Histoire Naturelle de Marseille 1: 306347.

Birdsall J., LitTlefield J., DE MeIj A. 2019. The risk potential of the Eastern Heath Snail, Xerolenta $o b$ via, in Montana. Abstract volume. World Congress of clutch sizes) was positively correlated with shell size of T. pisana and C. virgata (BAKER 1991).

In our study the duration of egg stage in X. obvia varied widely and hatching was asynchronous. Such differences can be attributed to the temperature. A wide range of times to hatching is usually explained by possible egg retention (TOMPA 1984). However, $X$. obvia was kept in constant laboratory conditions with no signs indicating egg retention. Furthermore, variation in the egg size negatively changed rates of juvenile growth and the timing of maturation in a slug Deroceras laeve (O. F. Müller, 1774) (SHIBATA \& ROLLO 1988).

\section{ACKNOWLEDGEMENTS}

We are grateful to JOHN HUTCHINSON for his helpful comments and suggestions on the manuscript as well as English correction. We also thank an anonymous reviewer for valuable remarks.

Malacology, August 11-16, 2019, Pacific Grove, CA, USA, p. 233.

BONAVITA A. 1965. Révision et étude écologique des Helicellines de Provence. Thesis, University of AixMarseille, Marseille.

BOUCHET P., ROCROI J-P. 2005. Classification and nomenclator of gastropod families. Malacologia 47: 1-397.

COWIE R. H. 1984. The life-history and productivity of the land snail Theba pisana (Mollusca: Helicidae). Journal of Animal Ecology 53: 311-325. https://doi. org/10.2307/4359

Cowie R. H., Dillon R. T., Robinson D. G., SMITH J. W. 2009. Alien non-marine snails and slugs of priority quarantine importance in the United States: a preliminary risk assessment. American Malacological Bulletin 27: 113-132. https://doi.org/10.4003/006.027.0210

DedoV I. K., Schneppat U. E., Glogger F. K. 2015. Hygromia cinctella (Draparnaud, 1801) (Mollusca: Gastropoda: Hygromiidae), a new snail species for the fauna of Bulgaria. Acta Zoologica Bulgarica 67: 465-469.

EHRMANN P. 1933. Mollusken (Weichtiere). In: BROHMER P., EhrmanN P., Ulmer G. (eds). Die Tierwelt Mitteleuropas. Vol 2. Quelle \& Meyer, Leipzig, pp. $1-264$.

Forsyth R. G., Oldham M. J., SNyder E., SCHUeler F. W., LAYBERRY R. 2015. Forty years later: distribution of the introduced Heath Snail, Xerolenta obvia, in Ontario, Canada (Mollusca: Gastropoda: Hygromiidae). Check List 11 (4): 1711. https://doi.org/10.15560/11.4.1711

FRÖMMING E. 1954. Biologie der mitteleuropäischen Landgastropoden. Duncker und Humblot, Berlin.

GRIMM F. W., WigGINS G. B. 1975. Colonies of the European snail Helicella obvia (Hartmann) in Ontario. The Canadian Field-Naturalist 88: 421-428. 
HATteland B. A., Roth S., ANDERSEN A., KAASA K., STøA B., SOLHøY T. 2013. Distribution and spread of the invasive slug Arion vulgaris Moquin-Tandon in Norway. Fauna Norvegica 32: 13-26. https://doi.org/10.5324/ fn.v32i0.1473

HÄNSEl N., WALTher CH., Plachter H. 1999. Influence of land use and habitat parameters on populations of Candidula unifasciata and Helicella itala (Gastropoda, Helicidae) on calcareous grassland. Verhandlungen der Gesellschaft für Ökologie 29: 363-372.

HELLER J. 2001. Life history strategies. In: BARKER G. M. (ed.). The biology of terrestrial molluscs. CABI Publishing, Wallingford, pp. 413-445. https://doi. org/10.1079/9780851993188.0413

Kerney M. P., CAmeron R. A. D., Jungbluth J. 1983. Die Landschnecken Nord- und Mitteleuropas. Verlag Paul Parey, Hamburg und Berlin.

Kiss L., LABAUne C., MAGNin F., AubRY S. 2005. Plasticity of the life cycle of Xeropicta derbentina (Krynicki, 1836), a recently introduced snail in Mediterranean France. Journal of Molluscan Studies 71: 221-231. https://doi. org/10.1093/mollus/eyi030

KRAMARENKO S. S. 2002. The pecularities of crossing and reproduction of the land snail Xeropicta derbentina (Pulmonata, Hygromiinae) at the Northern boundary of its range. Vestnik Zoologii 36: 55-60.

LAZARIDOU-DIMITRIADOU M. 1981. Contribution á l'étude biologique et écologique des escargots Cernuella virgata (Da Costa) et Xeropicta arenosa Ziegler (Gastropoda, Pulmonata) vivant sur les microdunes de Potidea, Chalkidiki (Gréce due Nord). In: ANFOssI G., Brambilla G., Violani C. (eds). Convegno Nazionaledella Società Malacologica Italiana. Aurora, Pavia, pp. 73-83.

LAZARIDOU-DIMITRIADOU M. 1995. The life cycle, demographic analysis, growth and secondary production of the snail Helicella (Xerothracia) pappi (Schut, 1962) (Gastropoda: Pulmonata) in E. Macedonia (Greece). Malacologia 37: 1-11.

LAZARIDOU M., ChATZIIOANNOU M. 2005. Differences in the life histories of Xerolenta obvia (Menke, 1828) (Hygromiidae) in a coastal and a mountainous area of northern Greece. Journal of Molluscan Studies 71: 4752. https://doi.org/10.1093/mollus/eyi032

MARZEC M., KuŹNIK-KowAlSKA E., ProćKóW M. 2020. Shell morphology, growth pattern and population dynamics of the land snail Xerolenta obvia (Menke, 1828) in two areas of different climatic conditions within a temperate climate region. Acta Zoologica Academiae Scientiarum Hungaricae 66: 69-84. https://doi. org/10.17109/AZH.66.1.69.2020

MOQUIN-TANDON A. 1855. Histoire naturelle des mollusques terrestres et fluviatiles de la France contenant des études générales sur leur anatomie et leur physiologie et la description particulière des genres, des espèces et des variétés. Tome second. Baillière, Paris. https://doi. org/10.5962/bhl.title.13098

PÁll-Gergely B., Majoros G., Domokos T., Juhász A., Turóci Á., BADACSONYI L., FeKETE J., AsAmi T. 2019. Realtime Social Networking Service rapidly reveals dis- tributions of non-indigenous land snails in a European capital. BioInvasions Records 8: 782-792. https://doi. org/10.3391/bir.2019.8.4.06

PeltanovÁ A., Petrusek A., KMENT P., JuŘičKovÁ L. 2012. A fast snail's pace: colonization of Central Europe by Mediterranean gastropods. Biological Invasions 4: 759764. https://doi.org/10.1007/s10530-011-0121-9

POMEROY D. E. 1969. Some aspects of the ecology of the land snail, Helicella virgata, in South Australia. Australian Journal of Zoology 17: 495-514. https://doi. org/10.1071/ZO9690495

Popov V. N., DragomaschenKo L. A. 1997. Aspect of the life cycle of land snails of the genus Xeropicta Monterosato, 1892 in Crimea (Pulmonata: Hygromiinae). Heldia 4: 114.

ProćKów M., KONOWALIK K., ProćKów J. 2019. Contrasting effects of climate change on the European and global potential distributions of two Mediterranean helicoid terrestrial gastropods. Regional Environmental Change 19: 2637-2650. https://doi.org/10.1007/ s10113-019-01573-W

RAZKIN O., GÓMEZ-MOLINER B. J., PRIETO C. E., MARTÍNEZOrtí A., Arrébola J. R., MuÑoz B., Chueca L. J., MADEIRA M. J. 2015. Molecular phylogeny of the western Palearctic Helicoidea (Gastropoda, Stylommatophora). Molecular Phylogenetics and Evolution 83: 99-117. https://doi.org/10.1016/j.ympev.2014.11.014

RIEDEL A. 1988. Ślimaki lądowe (Gastropoda terrestria). Katalog fauny Polski 36. Wydawnictwo Naukowe PWN, Warszawa.

SARMA R. R., MUNSi M., ANANTHRAM A. N. 2015. Effect of climate change on invasion risk of giant African snail (Achatina fulica Férussac, 1821: Achatinidae) in India. PLoS One 10: e0143724. https://doi.org/10.1371/ journal.pone.0143724

SCHILEYKO A. A. 2006. Treatise on recent terrestrial pulmonate molluscs. Part 14. Helicodontidae, Ciliellidae, Hygromiidae. Ruthenica Suppl. 2: 1907-2047.

SHIBATA D. M., ROLLO C. D. 1988. Intraspecific variation in the growth rate of gastropods: Five hypotheses. Memoirs of the Entomological Society of Canada 146: 199-213. https://doi.org/10.4039/entm120146199-1

STAIKOU A., LAZARIDOU-DIMITRIADOU M. 1991. The life cycle, population dynamics, growth and secondary production of the snail Xeropicta arenosa (Müller, 1774) (Gastropoda: Pulmonata) in northern Greece. Zoological Journal of the Linnean Society 101: 179-188. https://doi.org/10.1111/j.1096-3642.1991.tb00892.x

TOMPA A. S. 1984. Land Snails (Stylommatophora). In: TOMPA A. S., VERDONK N. H., VAN DEN BigGELAAR J. A. M. (eds). The Mollusca 7. Reproduction. Academic Press, Orlando, San Diego, San Francisco, New York, London, Sydney, Tokyo, Sao Paulo, pp. 47-140. https:// doi.org/10.1016/B978-0-08-092659-9.50009-0

URBAŃSKI J. 1957. Krajowe ślimaki i małże. Państwowe Zakłady Wydawnictw Szkolnych, Warszawa.

WALTON K. 2017. Hygromia cinctella (Draparnaud, 1801) (Mollusca: Gastropoda: Hygromiidae): a new adventive land snail for New Zealand. New Zealand Journal of 
Zoology 44: 9-13. https://doi.org/10.1080/03014223. 2016.1210653

WELTER-SCHULTES F. 2012. European non-marine molluscs, a guide for species identification. Planet Poster Editions, Göttingen.

White-MCLEAN J. A. 2011. Terrestrial Mollusc Tool. USDA/APHIS/PPQ Center for Plant Health Science and Technology and the University of Florida. Available online at http://idtools.org/id/mollusc (accessed 5th March 2020).

WIKTOR A. 2004. Ślimaki lądowe Polski. Mantis, Olsztyn.
WOJTAŚ W., WOJTAŚ-STOKŁOSA A. 2001. Ślimak przydrożny Helicella obvia (Menke). Wszechświat 102: 50-51.

ZEMOGLYADCHUK K. 2019. Population size structure and life cycle of the land snail Xerolenta obvia (Gastropoda, Hygromiidae) in Baranowitchy town. In: Zoological Readings. Publications of International Scientific and Practical Conference, 20-22.03.2019: 114-116.

Received: December 29th, 2019

Revised: March 31st/June 23rd, 2020

Accepted: June 26th, 2020

Published on-line: July 15th, 2020 